\title{
Examination of energy utilization in cattle offered a forage diet at near- and sub-maintenance levels of feeding
}

\author{
BY S. B. CAMMELL\&, M. J. HAINES, M. GILL* M. S. DHANOA†, J. FRANCE \\ AND D. E. BEEVER $\S$ \\ AFRC Institute of Grassland and Environmental Research, Hurley, Maidenhead, \\ Berkshire SL6 $5 L R$
}

(Received 18 August 1992 - Accepted 3 October 1992)

\begin{abstract}
Eight Friesian calves were reared from birth to the start of the experiment at a predetermined growth rate of $1.0 \mathrm{~kg} / \mathrm{d}$. Four calves (group 1) commenced the experiment at 22 weeks of age and the remainder (group 2) at 34 weeks, and feed intake was calculated to provide sufficient metabolizable energy to sustain zero energy balance $\left(E_{m}\right)$. Between experimental days 30 and 56 at maintenance levels of feeding, respiratory exchange measurements were made using open-circuit calorimetry to provide indirect estimates of heat production $(\mathrm{H})$ simultaneous with measurements of faecal and urinary excretion of energy and $\mathbf{N}$. A datum point for $E_{m}$ and $\mathrm{H}$ was established for each animal giving mean values for $E_{m}$ of 491 and 537 and for $H$ of 476 and $511 \mathrm{~kJ} / \mathrm{kg}$ live weight $(\mathrm{LW})^{0.75}$ per $\mathrm{d}$ for groups 1 and 2 respectively. Treatment levels calculated as $0.25,0.5,0.75$ and 1.25 of dry matter intake required to sustain the measured $E_{m}$, were imposed on individual animals after day 56 and further measurements of $\mathrm{H}$ and faecal/ urinary balance were made between days 72 and 84 followed by measurements of fasting heat production (FHP) during days 86-90 from the two animals in each group which had received the 0.75 and 1.25 levels of intake. Regression analysis of the treatment levels indicated separate linear models which predicted $E_{m}$ at 419 and $473 \mathrm{~kJ} / \mathrm{kg} \mathrm{LW}^{0.75}$ per $\mathrm{d}$ for groups 1 and 2 respectively. The incorporation of FHP with partitioning of faecal and urinary energy losses measured during fasting altered the relationship but not the predicted $E_{m}$. Overall predicted $E_{m}$ (days $72-84$ ) from all models were 406 and $478 \mathrm{~kJ} / \mathrm{kg} \mathrm{LW}^{\mathbf{0} 75}$ per $\mathrm{d}$ for groups 1 and 2 respectively which were significantly lower $(P<0.05)$ than $E_{m}$ measured during days 30-56.
\end{abstract}

Metabolizable energy: Maintenance feeding: Calorimetry

The UK metabolizable energy (ME) system (Agricultural Research Council, 1980) is primarily based on the results of a large number of animal calorimetry studies undertaken to evaluate concepts relating to the partitioning of food energy (Blaxter, 1962).

The efficiencies with which ME is used for the maintenance of the animal $\left(k_{m}\right)$ and for growth and fattening $\left(k_{f}\right)$ have been summarized by a simple piece-wise linear model intersecting at zero energy retention (Blaxter \& Wainman, 1961). These conventions have subsequently been used to define efficiencies of energy utilization despite the mathematical inaccuracies which are known to occur at levels of feeding substantially above maintenance requirements (Blaxter \& Graham, 1955; Blaxter \& Boyne, 1970, 1978; Agricultural Research Council, 1980).

\footnotetext{
Present addresses:

* Natural Resources Institute, Central Avenue, Chatham Maritime, Kent ME4 4TB.

$\dagger$ AFRC Institute of Grassland and Environmental Research, Plas Goggerdan, Aberystwyth, Dyfed SY23 3EB.
}

$\ddagger$ AFRC Institute of Grassland and Environmental Research, North Wyke Research Station, Okehampton, Devon EX20 2SB.

$\S$ Department of Agriculture, University of Reading, Reading RG6 2AT, and for reprints. 
The Mitscherlich equation for describing the response of energy retention rate to increments in $\mathrm{ME}$ intake (MEI) was proposed as an alternative to the piece-wise linear model (Blaxter \& Boyne, 1978), and was used by Cammell et al. (1986) to compare $k_{f}$ values for perennial ryegrass (Lolium perenne) and white clover (Trifolium repens) fed to growing steers at medium and high MEI, also, using measured values from the same group of animals for fasting heat production (FHP), to extrapolate to $k_{m}$ and ME maintenance requirements.

Implicit in such an analysis was the assumption that no pronounced curvilinearity existed between retained energy (RE) and MEI at low and negative energy balance. The mathematical consequences of curvature were studied by France et al. (1989) who proposed alternative models for data analysis.

The present study was undertaken to investigate whether curvilinearity existed at low and negative energy balance and, in consideration of animal welfare, to assess the feasibility of replacing fasting protocol with sub-maintenance levels of feeding as a pre-requisite to the determination of $k_{m}$ and the level of ME necessary to sustain zero energy balance $\left(E_{m}\right)$.

\section{EXPERIMENTAL METHODS}

Animals and experimental design

Eight Friesian male castrate calves (mean live weight (LW) $46 \mathrm{~kg}$ ) were reared on milk substitute for 6 weeks followed by hay and concentrates to 22 weeks of age when the experiment commenced. At this time the animals were divided into two groups on the basis of LW with the four heaviest animals (LW range 210-220 (mean 216) kg) and the four lightest animals (LW range 190-205 (mean 196) $\mathrm{kg}$ ) allocated to groups 1 and 2 respectively.

The experiment was conducted over a period of $90 \mathrm{~d}$ for each group of calves, but as only two respiration chambers were available group 2 calves were maintained on the preexperimental diet of hay and concentrates for a further 12 weeks before starting the experiment, by which time they had attained a LW range of $258-275$ (mean 264) kg. Both groups received identical feed and experimental treatments. The four calves in each group were paired and the timing of $\mathrm{N}$ balance and calorimetry measurements for each pair were staggered by $6 \mathrm{~d}$ to provide continuity in use of the respiration chambers.

All animals were fed at levels calculated to maintain zero energy balance during days $1-56$ of the experiment, with energy partition being measured during days $16-21,30-35$ and 51-56. Following this, one animal from each group was randomly allocated to a feeding allowance of either $0 \cdot 25,0 \cdot 5,0 \cdot 75$ or $1 \cdot 25$ of the maintenance (M) dry matter (DM) intake measured during days $35-56$.

All animals were established on the new feeding levels during days 57 and 58 and sustained at these allowances up to day 84 , with measurements of energy partition being conducted between days 79-84. Between days 86 and 90 the calves on the $0.75 \mathrm{M}$ and $1.25 \mathrm{M}$ treatments $(n)$ were used for the estimation of FHP.

\section{Diet allocation}

All animals received the same diet of dried grass cob and chopped grass hay $(50: 50, \mathrm{w} / \mathrm{w}$, on a DM basis). During days 1-56 the amount of feed calculated to maintain zero energy balance was estimated using the equation of Terry et al. (1974):

$$
\mathrm{DE}(\mathrm{MJ} / \mathrm{kg} \mathrm{DM})=0 \cdot 1233 \mathrm{CP}(\%)+0 \cdot 1705 \mathrm{DOMD}(\%)+0 \cdot 285
$$

where $\mathrm{DE}$ is digestible energy, $\mathrm{CP}$ is crude protein $(\mathrm{N} \times 6.25)$ and DOMD is digestible organic matter in the DM. 
$\mathrm{ME}$ content $\left(\mathrm{ME}_{\mathrm{c}}\right)$ of the diet was estimated using the relationship:

$$
\mathrm{ME}_{\mathrm{c}}=0.81 \mathrm{DE}
$$

and initial levels of MEI to support maintenance were calculated as

$$
0.46 \mathrm{MJ} \mathrm{MEI} / \mathrm{kg} \mathrm{LW}^{0.75} \text { per d as suggested by Vermorel et al. (1980). }
$$

The levels of feeding for each individual animal were adjusted during days 1-15 of the experiment using daily LW measurements. Final adjustments to MEI were made on the basis of heat production $(\mathrm{H})$ and MEI measured during days 16-21 before subsequent measurements of energy partition at days 30-35 and 51-56.

During days 57 and 58 the levels of feeding were adjusted to the four multiples of the DM offered to maintain zero energy balance during days 35-56 with no further adjustment for subsequent $\mathrm{LW}$ changes until day 84 .

\section{Experimental procedures}

All animals were acclimatized to metabolism crates and respiration chambers during the 4 weeks before commencement of the experiment and feeding levels were adjusted to the estimated individual maintenance requirements (equations 1,2 and 3) during the last $14 \mathrm{~d}$ of this period. Consumption of food DM and faecal and urinary outputs were measured during days 16-21, 23-28, 30-35, 44-49 and 51-56 of maintenance level feeding using procedures described by Cammell (1977). A resting period in a non-bedded pen area was allowed during days $36-42$. The calves were also placed in open-circuit respiration chambers during days 16-21, 30-35 and 51-56, comprising $3 \mathrm{~d}$ for acclimatization and three consecutive $24 \mathrm{~h}$ measurements of respiratory exchange (Cammell et al. 1981, 1986) simultaneous with digestibility and $\mathrm{N}$ balance measurements. Animals were then adjusted as previously described during days 57 and 58 to the designated treatment levels and, following a resting period during days 57-63, feed intake and faecal and urine outputs were measured during days $72-77$ and 7984 with respiratory exchange measured during days $79-84$ only.

Subsequently, the calves on treatments 0.75 and 1.25 were retained in respiration chambers for a further $6 \mathrm{~d}$ during which time FHP was measured using procedures described by Blaxter (1962), with the exception that total length of fast was $96 \mathrm{~h}$ with the measurement of respiratory exchange between 48 and $96 \mathrm{~h}$. Faeces and urine collections were made daily during the period of fasting.

LW was recorded daily throughout the whole experiment between 09.00 and 10.00 hours for all animals in order to monitor the stability of LW and facilitate dietary adjustments where necessary. Animals were offered equal amounts of diet twice daily at 10.00 and 22.00 hours together with a mineral supplement. Fresh drinking water was available at all times. All calves were housed indoors throughout the period of the experiment and were not exposed to extreme changes in either ambient or environmental conditions.

\section{Preparation and analysis of samples}

Samples of feed were taken daily, subsequently freeze-dried, then ground through a small laboratory mill. The faeces voided daily were mixed and a representative sample comprising $150 \mathrm{~g} / \mathrm{kg}$ total daily fresh weight production was stored at $-5^{\circ}$. Individual daily samples were subsequently mixed after defrosting and a representative sample $(200 \mathrm{~g}$ ) was freezedried for chemical analysis. The remainder was bulked with other individual daily samples, thoroughly mixed and three $500 \mathrm{~g}$ portions dried at $100^{\circ}$ for $48 \mathrm{~h}$ to determine DM content.

Samples of feed and faeces were analysed for organic matter (ashing at $500^{\circ}$ overnight), total N (micro-Kjeldahl) and gross energy (GE) content (adiabatic calorimeter). Acidified 
$\left(10 \mathrm{M}-\mathrm{H}_{2} \mathrm{SO}_{4}\right)$ urine samples were collected daily, mixed thoroughly and subsampled ( $10 \mathrm{ml} / 1$ total daily volume) and analysed for $\mathrm{N}$ content by micro-Kjeldahl using the fresh sample. GE content was determined using an adiabatic bomb calorimeter after preparation of the samples. This involved measurement of $10 \mathrm{ml}$ acidified urine into a preweighed polythene 'finger' which, after accurate weighing, was neutralized with saturated $\mathrm{NaOH}$. The 'finger' was then partially closed with a standard length of firing cotton and frozen for $24 \mathrm{~h}$ before freeze-drying and subsequent GE determination. Samples were prepared in triplicate for estimation of GE content.

\section{Calculations and statistical analysis}

$\mathrm{H}$ was estimated from gaseous exchange and urinary $\mathrm{N}$ output using the equation of Brouwer (1965). RE was calculated as the difference between MEI and $H$. The values obtained during the period of maintenance level feeding were excluded from the analysis of the data relating to treatment levels $0.25-1.25$ in order to permit a comparison of predicted with measured MEI at zero energy balance.

Values for FHP were initially obtained using the convention RE = MEI - FHP, where $\mathrm{MEI}=0$ and FHP is total energy output as $\mathrm{H}$. However, despite a $48 \mathrm{~h}$ fast before the measurement of $\mathrm{H}$, there was a continued output of faeces and urine which amounted to approximately $0.40 \mathrm{H}$. This difficulty encountered in achieving either minimal or zero output of faeces and urine resulted in the previously stated relationship being modified to account for these outputs where MEI was assumed to be either zero or zero minus faecal energy (FE) and FHP assumed to be H plus urine energy (UE).

These calculations were an attempt to represent a more accurate partition of energy costs during fasting while describing the shape of the response to increments of ME between zero MEI, $E_{m}$ and $1.25 \mathrm{M}$. RE and MEI data were scaled using metabolic LW ( $\mathrm{LW}^{0.75}$ ) and regression analysis was undertaken using the conventions for fasting metabolism described previously. An additional analysis was also considered which excluded the data sets for fasting metabolism. Group 1 and 2 animals were tested separately to establish whether differences existed due to age and/or LW.

The prediction of $E_{m}$ required to maintain zero energy balance was determined from the best fit models for each data set and confidence intervals $(\mathrm{CI})$ were calculated according to the formula of Williams (1959). Differences between predicted and measured MEI at zero energy balance were tested for significance.

\section{RESULTS}

\section{Energy balance at maintenance}

The chemical composition of the diet remained constant throughout the experiment and although small changes occurred in moisture content due to ambient conditions this had minimal effect upon the intake of GE and $\mathrm{N}$. The mean values for the composition of the dried grass cob and grass hay respectively were 870 and $850 \mathrm{~g} \mathrm{DM} / \mathrm{kg}$ fresh weight, 907 and $923 \mathrm{~g}$ organic matter/kg DM, 18.17 and $18.07 \mathrm{MJ} \mathrm{GE} / \mathrm{kg} \mathrm{DM}$, and 23.8 and $16.7 \mathrm{~g} \mathrm{~N} / \mathrm{kg}$ DM.

The daily LW measurements provided an opportunity for routine assessment of the clinical condition of each animal throughout the experiment. No major physiological or metabolic disorders occurred in any animal.

Initially MEI was adjusted downwards during days 1-14 of the experiment using daily LW change. Thereafter, measurements of $\mathrm{N}$ balance and MEI simultaneous with respiratory exchange during days 16-21 permitted a more accurate assessment of $\mathrm{H}$ and MEI and no major adjustments to MEI were necessary after day 21. 
Table 1. The metabolizable energy intake (MEI) and heat production $(H)$ by Friesian calves maintained at zero energy balance (mean values measured during days 30-35 and 51-56) and predicted $H$ using relationships proposed by the Agricultural Research Council (1980)*

(Values are expressed as $\mathrm{MJ} / \mathrm{d}$ )

\begin{tabular}{|c|c|c|c|c|c|c|}
\hline \multirow[b]{2}{*}{ Group no. } & \multirow[b]{2}{*}{ Animal no. } & \multicolumn{2}{|c|}{ Measured } & \multicolumn{3}{|c|}{ Predicted } \\
\hline & & MEI & $\mathbf{H}$ & $\mathrm{H}^{1} \dagger$ & $\mathrm{H}^{2}+$ & $\mathrm{LW}^{0.75}$ \\
\hline \multirow[t]{4}{*}{1} & 1 & $27 \cdot 89$ & $27 \cdot 38$ & $29 \cdot 24$ & - & 57.31 \\
\hline & 2 & 27.97 & 26.82 & $28 \cdot 50$ & - & 55.90 \\
\hline & 3 & $26 \cdot 28$ & $26 \cdot 45$ & 27.64 & $25 \cdot 12$ & 53.84 \\
\hline & 4 & 26.92 & $25 \cdot 04$ & $28 \cdot 36$ & 26.00 & $55 \cdot 15$ \\
\hline SEM & & 0.651 & 0.534 & - & - & 0.172 \\
\hline \multirow[t]{4}{*}{2} & 5 & $34 \cdot 89$ & $34 \cdot 72$ & $32 \cdot 48$ & - & $64 \cdot 38$ \\
\hline & 6 & $34 \cdot 27$ & $31 \cdot 54$ & 32.63 & - & 64.49 \\
\hline & 7 & $35 \cdot 28$ & $34 \cdot 17$ & $32 \cdot 08$ & $31 \cdot 12$ & 63.81 \\
\hline & 8 & $34 \cdot 00$ & $31 \cdot 29$ & $33 \cdot 11$ & 37.52 & $65 \cdot 36$ \\
\hline SEM & & 0.528 & $0 \cdot 540$ & - & - & 0.525 \\
\hline
\end{tabular}

LW, live weight.

* For details of experimental procedures, see pp. 382-383.

+ Predicted using equations 4 and 5 (see below) using mean LW from days 30-35 and 51-56.

$\ddagger$ Using measured fasting heat production and predicted efficiency of use of metabolizable energy for maintenance calculated according to equation 5 (see below).

LW stability was attained by day 25 and this equilibrium $( \pm 1.5 \mathrm{~kg})$ was maintained up to day 56 when treatment levels were imposed. The maintenance of animals at constant body weight has been shown to result in a steady decline in feed requirements (Ledger \& Sayers, 1977); however, no significant changes in MEI and $\mathrm{H}$ were observed $(P>0.05)$ after day 21 for either group.

The measured values (means for each of eight calves) during experimental days 30-35 and 51-56 for MEI and $\mathrm{H}(\mathrm{MJ} / \mathrm{d})$ are given in Table 1 . There was no significant difference $(P>0.05)$ between measured MEI and $\mathrm{H}$ although mean $\mathrm{MEI}$ for all animals exceeded estimates of $\mathrm{H}$ by $1.26 \mathrm{MJ} / \mathrm{d}$, equivalent to an estimated $60 \mathrm{~g} \mathrm{LW}$ gain $/ \mathrm{d}$. There was, however, a significant difference $(P<0.001)$ between groups 1 and 2 with respect to overall MEI (27.27 and $34.61 \mathrm{MJ} / \mathrm{d})$ and $\mathrm{H}(26.42$ and $32.93 \mathrm{MJ} / \mathrm{d})$ and this difference remained when the values were expressed on a metabolic LW basis; MEI 491 and 537, and H 476 and $511 \mathrm{~kJ} / \mathrm{kg} \mathrm{LW}^{0.75}$ per d respectively. Table 1 also gives values of $\mathrm{H}$ at zero energy balance $\left(\mathrm{H}^{1}\right)$ predicted from the relation $\mathrm{Z} / k_{m}$ (Agricultural Research Council, 1980) where $\mathrm{Z}$ is defined as minimal metabolism $(\mathrm{MJ} / \mathrm{d})$ and $k_{m}$ as the efficiency of utilization of $\mathrm{ME}$ for maintenance:

$$
\begin{aligned}
\mathrm{Z} & =0.53(\mathrm{~W} / 1.08)^{0.67}+0.0043 \mathrm{~W}, \\
k_{m} & =0.35\left(\mathrm{ME}_{\mathrm{c}} / \mathrm{GE}_{\mathrm{c}}\right)+0.503,
\end{aligned}
$$

where $W$ represents $L W$ and $M E_{c}$ and $G_{c}$ represent $M E$ and GE concentrations respectively $(\mathrm{MJ} / \mathrm{kg} \mathrm{DM}$ ). Individual LW values (mean of days 30-35 and 51-56) were used in equation 4 to derive $Z$ and individual values for the metabolizability $(q)$ of dietary $\mathrm{GE}\left(\mathrm{ME}_{\mathrm{c}} / \mathrm{GE}_{\mathrm{c}}\right)\left(\right.$ mean 0.486 (SE 0.0040)) were used in equation 5 to derive $k_{m}$ (mean 0.673 (SE 0.0027)).

There was no significant difference $(P>0 \cdot 05)$ between the predicted values $\left(\mathrm{H}^{1}\right.$; Table 1 ; means 28.44 and $32.58 \mathrm{MJ} / \mathrm{d}$ ) at zero energy balance and the measured data (means 
Table 2. The metabolizable energy intake (MEI), heat production $(H)$ and retained energy $(R E)$ during days 79-84 by Friesian calves receiving levels of feed (LoF) calculated from the maintenance $(M)$ period of feeding*

(Values are expressed as $\mathrm{kJ} / \mathrm{kg}$ live weight $(\mathrm{LW})^{\mathbf{0} \cdot 75}$ per $\mathrm{d}$ )

\begin{tabular}{|c|c|c|c|c|c|c|}
\hline Group no. & Animal no. & $\mathrm{LoF}^{\dagger}$ & MEI & $\mathrm{H}$ & RE & $\mathrm{LW}^{0.75}+$ \\
\hline 1 & $\begin{array}{l}1 \\
2 \\
3 \\
4\end{array}$ & $\begin{array}{l}0.25 \mathrm{M} \\
0.50 \mathrm{M} \\
0.75 \mathrm{M} \\
1.25 \mathrm{M}\end{array}$ & $\begin{array}{l}123 \\
271 \\
394 \\
576\end{array}$ & $\begin{array}{l}313 \\
352 \\
428 \\
475\end{array}$ & $\begin{array}{r}-190 \\
-81 \\
-34 \\
+101\end{array}$ & $\begin{array}{l}51 \cdot 38 \\
51 \cdot 55 \\
51 \cdot 52 \\
58 \cdot 00\end{array}$ \\
\hline SEM & $\begin{array}{l}5 \\
6 \\
7 \\
8\end{array}$ & $\begin{array}{l}0.25 \mathrm{M} \\
0.50 \mathrm{M} \\
0.75 \mathrm{M} \\
1.25 \mathrm{M}\end{array}$ & $\begin{array}{r}132 \\
299 \\
435 \\
642 \\
9 \cdot 0\end{array}$ & $\begin{array}{r}393 \\
425 \\
447 \\
528 \\
5.9\end{array}$ & $\begin{array}{r}-261 \\
-126 \\
-12 \\
+114 \\
5 \cdot 3\end{array}$ & $\begin{array}{c}57 \cdot 58 \\
59 \cdot 57 \\
61 \cdot 50 \\
68 \cdot 15 \\
0.901\end{array}$ \\
\hline
\end{tabular}

* For details of experimental procedures, see pp. 382-383.

$\dagger$ For details of LoF regimen, see pp. 382-383.

$\ddagger$ Mean LW during days 79-84.

26.42 and $32.93 \mathrm{MJ} / \mathrm{d}$ ) for groups 1 and 2 respectively. Over all, for all animals the predicted heat production $(30.51 \mathrm{MJ} / \mathrm{d})$ was approximately 0.027 greater than the observed value $(29.68 \mathrm{MJ} / \mathrm{d}$ ). Furthermore, when heat production was predicted using FHP (animals nos. $3,4,7,8)$ to replace equation 4 together with $k_{m}$ from equation $5\left(\mathrm{H}^{2}\right.$; Table 1$)$ the mean value $(29.94 \mathrm{MJ} / \mathrm{d})$ did not differ significantly $(P>0.05)$ from the observed value $(29.24 \mathrm{MJ} / \mathrm{d})$, although the predicted value for animal no. 8 was almost $0 \cdot 2$ higher due to an elevated FHP which may have resulted from the 1.25 level of feeding for this animal before fasting. The mean value for FHP (animals nos. 3, 4, 7 and 8) was $20 \cdot 1$ (SE 1.91) MJ/d (335 (SE 0.014$) \mathrm{kJ} / \mathrm{kg} \mathrm{LW}{ }^{0.75}$ per d) which when expressed in relation to $\mathrm{H}$ measured at maintenance gave a $k_{m}$ of 0.676 which approximated to the derived value of 0.673 from equation 5 .

\section{Energy exchange at sub-maintenance levels of feeding}

Table 2 gives values for MEI and $\mathrm{H}$ measured in calves receiving the treatment feeding levels calculated in respect of their measured maintenance DM requirements (i.e.: $0.25 \mathrm{M}$, $0.5 \mathrm{M}, 0.75 \mathrm{M}, 1.25 \mathrm{M}$ ). The treatment levels achieved were within $5 \%$ of the theoretical levels calculated on the basis of MEI measured at maintenance.

RE calculated as the difference between MEI and $\mathrm{H}$ indicated a significant response $(P$ $<0.001)$ between the two groups of calves. This difference was due to a significantly higher $\mathrm{H}$ for group 2 at the $0.25 \mathrm{M}$ and $0.5 \mathrm{M}$ levels of feeding $(P<0.01)$ which could, in part, be related to the maturity of group 2 animals where reduction in metabolic activity of body tissues and organs due to food restrictions may not have been as great as in younger animals (Ledger \& Sayers, 1977). Consequently, analysis of the data in Table 2 indicated that significant differences $(P<0.001)$ existed between the slopes for the relationships for the two groups of calves when represented by straight lines (Fig. 1(a)) relating RE to MEI $\left(\mathrm{kJ} / \mathrm{kg} \mathrm{LW}^{0.75}\right.$ per d) as follows:

$$
\begin{array}{ll}
\text { group 1 } & \mathrm{RE}=0.627 \mathrm{MEI}-263 \cdot 1, r 0.989, \text { residual SD (RSD) } 12 \cdot 79, \\
\text { group } 2 & \mathrm{RE}=0.746 \mathrm{MEI}-353 \cdot 0, r 0.994, \mathrm{RSD} 12 \cdot 19
\end{array}
$$

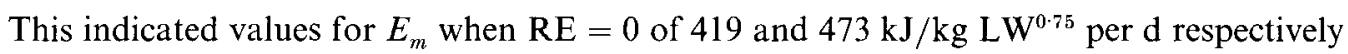


(a)

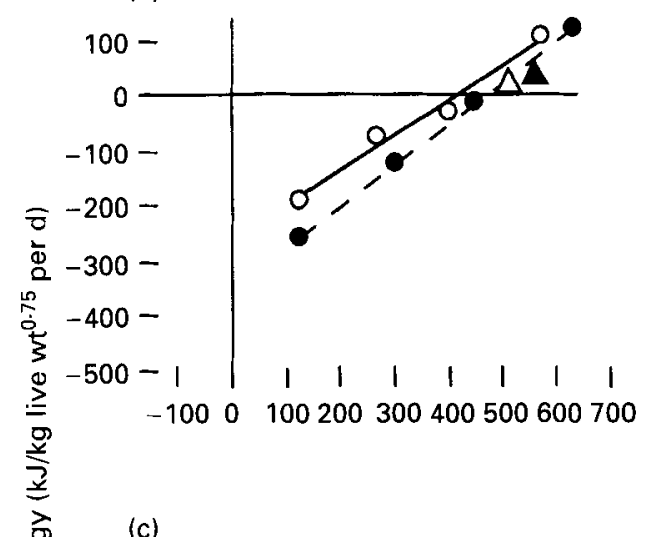

(c)

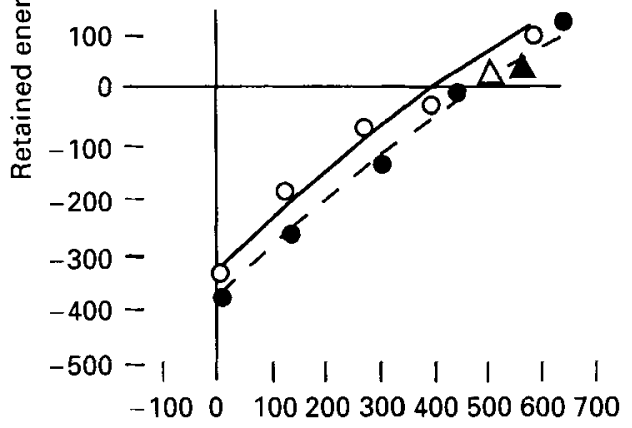

(b)

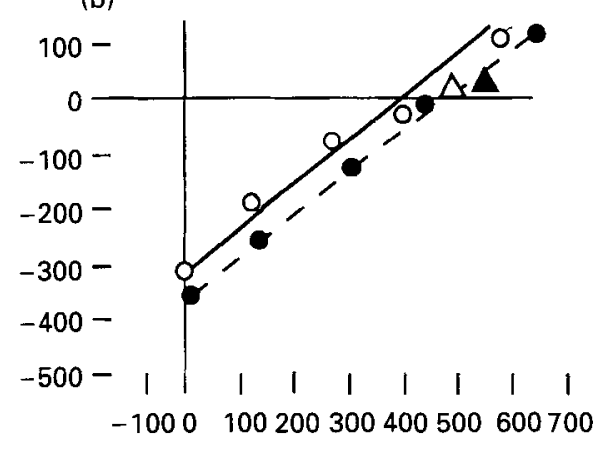

(d)

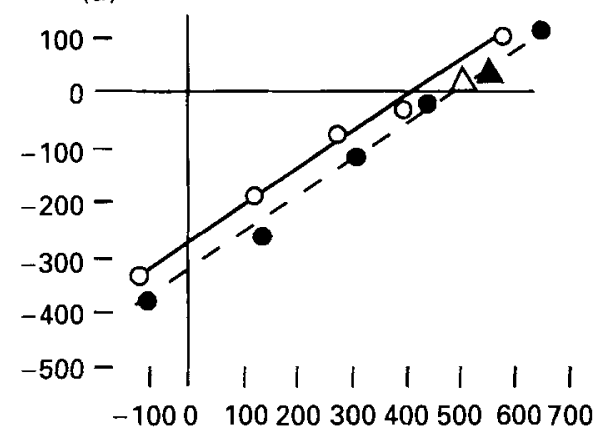

Metabolizable energy intake $\left(\mathrm{kJ} / \mathrm{kg}\right.$ live $\mathrm{wt}^{0.75}$ per d)

Fig. 1. The relationship between retained energy $(\mathrm{RE} ; \mathrm{O}, \mathbf{O})$ and metabolizable energy intake (MEI; ....) for group $1(\mathrm{O}-\mathrm{O})$ and group 2 (O-..-O) calves: (a) excluding fasting metabolism, (b) where $\mathrm{MEI}=0$ and REI $=0$-fasting heat production (FHP), (c) where MEI $=0$ and RE $-0-(\mathrm{FHP}+$ urine energy), (d) where $\mathrm{MEI}=0-$ faecal energy and $\mathrm{RE}=0-(\mathrm{FHP}+$ urine energy). Mean zero energy balance for group $1(\triangle)$ and group 2 (A) were measured during days 30-35 and days 51-56. The overall relationships were calculated according to (a) equations 6 and 7 , (b) equations 8 and 9 , (c) equations 10 and 11 , (d) equations 12 and 13 (for details, see pp. 386-389).

which differed significantly $(P<0.05)$ from each other and also from the mean values of 491 and $537 \mathrm{~kJ} / \mathrm{kg} \mathrm{LW} \mathrm{LW}^{0.75}$ per $\mathrm{d}$ for groups 1 and 2 respectively measured during maintenance feeding. Values for CI are given in Table 4.

Table 3 gives the partition of energy losses during fasting for the animals previously established on treatments $0.75 \mathrm{M}$ and $1.25 \mathrm{M}$. The mean values for energy lost as heat (mean respiratory quotient 0.72$)$ were not significantly different $(P>0.05)$ between group 1 and group 2 at 315 and $354 \mathrm{~kJ} / \mathrm{kg} \mathrm{LW} W^{0.75}$ per d respectively, whilst losses as faecal energy were still surprisingly high (115 and $102 \mathrm{~kJ} / \mathrm{kg} \mathrm{LW}^{0.75}$ per d). Urinary energy losses averaged 0.07 of $\mathrm{H}$, with total energy output from faeces, urine and methane sources ranging from 0.34 to $0.53 \mathrm{FHP}$. Thus, despite deliberate attempts to achieve the criteria for post-absorptive conditions (Blaxter, 1962), significant quantities of material continued to be voided, as observed earlier by Blaxter \& Wainman (1966). Subsequently the energy losses from heat and from faeces and urine, as given in Table 3, were used as specified in equations 8-13 (Fig. 1(b, c, d)) to examine further the relationship between MEI and RE using regression analysis to elucidate any significant departure from linearity for each group of animals. The resultant equations were also used to predict $E_{m}$ and these were 
Table 3. The partition of energy losses $\left(\mathrm{kJ} / \mathrm{kg}\right.$ live weight $(L W)^{0.75}$ perd $)$ by Friesian calves 72-96 h after commencement of fasting period*

\begin{tabular}{lcccccc}
\hline Group no. & Animal no. & Heat & Faeces & Urine & Methane & LW $^{0 \cdot 75} \dagger$ \\
\hline 1 & 3 & 330 & 105 & 24 & 8 & $51 \cdot 25$ \\
& 4 & 300 & 125 & 26 & 8 & $58 \cdot 19$ \\
2 & 7 & 341 & 93 & 17 & 7 & $61 \cdot 87$ \\
& 8 & 367 & 111 & 26 & 6 & $68 \cdot 48$ \\
SEM & $14 \cdot 3$ & $9 \cdot 5$ & $3 \cdot 4$ & $0 \cdot 2$ & $3 \cdot 390$ \\
\hline
\end{tabular}

* For details of experimental procedures, see pp. 382-384.

$\dagger$ LW at start of fasting period.

Table 4. Measured values and derived data with $90 \%$ confidence intervals $(C I)$ to predict the amounts of metabolizable energy $\left(\mathrm{kJ} / \mathrm{kg}\right.$ live weight $\left.t^{0.75} \mathrm{per} d\right)$ required by Friesian calves to maintain zero energy balance $\left(E_{m}\right)$

\begin{tabular}{lllll}
\hline \hline & Group no. & $\begin{array}{c}\text { Convention used } \\
\text { in Fig. I }\end{array}$ & $E_{m}$ & CI \\
\hline Measured & 1 & MEI $=\mathrm{H}$ & 491 & $476-505$ \\
Derived & 2 & & 537 & $522-551$ \\
Equation* & & & \\
6 & 1 & FHP not used & 419 & $398-444$ \\
7 & 2 & & 473 & $455-493$ \\
8 & 1 & MEI $=0$ & 409 & $385-450$ \\
9 & 2 & FHP $=\mathrm{H}$ & 478 & $456-491$ \\
10 & 1 & MEI $=0$ & 396 & $377-458$ \\
11 & 2 & FHP $=$ H + UE & 469 & $450-494$ \\
12 & 1 & MEI $=0-$ FE & 412 & $396-445$ \\
13 & 2 & FHP $=\mathrm{H}+\mathrm{UE}$ & 488 & $451-516$ \\
\hline \hline
\end{tabular}

FHP, fasting heat production; $\mathrm{H}$, heat production, MEI, metabolizable energy intake; UE, urine energy; FE, faecal energy.

* For equations 6-13, see pp. 386-389.

compared with the mean values measured during the maintenance feeding period and predicted using equations 6 and 7 .

In Fig. 1(b), incorporation of fasting metabolism, where RE is described by $\mathrm{MEI}=0$ and $\mathrm{FHP}=\mathrm{H}$, altered the separate linear relation (Fig. 1(a)) to a parallel linear model:

$$
\begin{array}{ll}
\text { group 1 } & \mathrm{RE}=0.730 \mathrm{MEI}-298 \cdot 6, \\
\text { group 2 } & \mathrm{RE}=0.730 \mathrm{MEI}-349 \cdot 3, \\
& (r 0.987, \mathrm{RSD} 18.45) .
\end{array}
$$

Thus, when $\mathrm{RE}=0$ the predicted $E_{m}$ values from these relationships were 409 and $478 \mathrm{~kJ} / \mathrm{kg} \mathrm{LW}{ }^{0.75}$ per d (groups 1 and 2 respectively), which were significantly different $(P$ $<0.05$ ) from the measured $E_{m}$ values of 491 and $537 \mathrm{~kJ} / \mathrm{kg} \mathrm{LW}^{0.75}$ per d (group 1 and 2), but not $(P>0.05)$ from the predicted values (equations 6 and 7$)$. CI are given in Table 4 .

In Fig. 1 (c), partitioning UE as a component of FHP so that RE was represented by 
variables, where $\mathrm{MEI}=\mathbf{0}$ and $\mathrm{FHP}=\mathrm{H}+\mathrm{UE}$, produced a significant $(P<0.001)$ curvilinear relationship between $\mathrm{MEI}$ and $\mathrm{RE}$, represented by a parallel quadratic model:

$$
\begin{array}{ll}
\text { group 1 } & \mathrm{RE}=0.970 \mathrm{MEI}-0.000357 \mathrm{MEI}^{2}-327 \cdot 8, \\
\text { group 2 } & \mathrm{RE}=0.970 \mathrm{MEI}-0.000357 \mathrm{MEI}^{2}-376 \cdot 4, \\
& (r 0.976, \mathrm{RSD} 19 \cdot 20) .
\end{array}
$$

Thus, when $\mathrm{RE}=0$ the predicted $E_{m}$ was significantly lower $(P<0.05)$ at 396 and $469 \mathrm{~kJ} / \mathrm{kg} \mathrm{LW}{ }^{0.75}$ per $\mathrm{d}$ for groups 1 and 2 respectively than the measured values but not than the values predicted using equations 6 and $7(P>0.05)$; see Table 4 for CI.

Partitioning FE as a negative component of MEI, with UE ascribed as before to FHP so that RE was represented by the variables $\mathrm{MEI}=0-\mathrm{FE}$ and $\mathrm{FHP}=0-(\mathrm{H}+\mathrm{UE})$, gave a parallel linear model (Fig. 1(d)).

$$
\begin{array}{ll}
\text { group 1 } & \mathrm{RE}=0.654 \mathrm{MEI}-269 \cdot 4, \\
\text { group 2 } & \mathrm{RE}=0.654 \mathrm{MEI}-319 \cdot 6, \\
& (r 0.988, \mathrm{RSD} 18.49) .
\end{array}
$$

Thus, when $\mathrm{RE}=0, E_{m}$ values of 412 and $488 \mathrm{~kJ} / \mathrm{kg} \mathrm{LW}^{0.75}$ per d MEI were estimated for groups 1 and 2 respectively. Once again these were significantly lower $(P<0.05)$ than the values measured during the maintenance feeding period but not $(P>0.05)$ than the $E_{m}$ predicted using equations 6 and 7 ; see Table 4 for CI.

In summary, the overall predicted values for $E_{m}$ were 406 (equations $8,10,12$ ) and 478 (equations $9,11,13) \mathrm{kJ} / \mathrm{kg} \mathrm{LW} \mathbf{6}^{0.75}$ per $\mathrm{d}$ for groups 1 and 2 respectively, which did not differ significantly $(P>0.05)$ from the values of 419 and 473 predicted using equations 6 and 7 but were significantly different $(P<0.05)$ from the measured values $(491$ and $537 \mathrm{~kJ} / \mathrm{kg}$ $\mathrm{LW}^{0.75}$ per $\mathrm{d}$ for group 1 and 2 calves respectively).

\section{DISCUSSION}

Methods for the determination of maintenance energy requirements and implications for use in feed evaluation systems have been reviewed by Armstrong \& Blaxter (1984). Blaxter (1972) emphasized that maintenance and productive processes could not be separated, recognizing that in, for example, pregnant and/or lactating animals physiological processes such as loss or repletion of body tissue, foetal development and milk production create variable demands for maintenance energy. It is clearly impossible for such categories of animals to meet the operational definition of energy required for maintenance in which, by definition, there is no substantive change, over a period of time, in body energy content for a constant input of ME. Such a condition implies the suspension of normal physiological development. Nevertheless it is a variable that has been used extensively in metabolic studies, together with FHP, as a benchmark from which efficiencies of utilization could be defined as a basis for food rationing systems (Agricultural Research Council, 1980), although it has been recognized that body-weight equilibrium is not necessarily synonymous with energy equilibrium (Armstrong \& Blaxter, 1984). There have been several studies with respect to the long-term measurement of these variables (Taylor \& Young, 1967, 1968; Ledger \& Sayers, 1977; Foot \& Tulloh, 1977; Webster et al. 1982) but there are few available findings where indirect calorimetry has been used in long-term studies to examine energy utilization at levels between an established ME equilibrium point and fasting metabolism.

From the present study the maintenance energy requirements for the two groups of calves measured at calculated ME intakes for zero energy retention were 491 and 537 (mean 
$514) \mathrm{kJ} / \mathrm{kg} \mathrm{LW}^{0.75}$ per $\mathrm{d}(q 0 \cdot 486)$, which were slightly higher than previously summarized findings (Van Es, 1961; Agricultural Research Council, 1980). These values probably reflect the effect of enhanced metabolic and physiological processes attributable to the rate of growth of these animals before restriction of feeding level (Webster, 1978). Using these values and the derived value for $k_{m}$ of 0.673 (equation $5 ; q 0.486$ ), the mean values for fasting metabolism were estimated as 330 and $361 \mathrm{~kJ} / \mathrm{kg} \mathrm{LW}$ LW $^{0.75}$ (groups 1 and 2 respectively) which equate with the measured FHP of 315 and 354 (mean group 1 and group 2 respectively) and compare broadly with the overall mean value of 351 derived from equation 4. As such these results support the published relationships (Agricultural Research Council, 1980) with respect to the derivations for maintenance energy requirement using predicted fasting metabolism and $k_{m}$ values.

The response to increments of ME between fasting metabolism and zero energy balance was examined in the present study. Interest in this component of energetic efficiency primarily arises from the assumed doctrine of linearity of the efficiency terms $k_{m}$ and $k_{f}$ and the difficulties that sometimes arise in meaningful biological interpretation of energy balance studies, particularly where considerable reliance is placed on extrapolation (Armstrong \& Blaxter, 1984). Curvilinearity of response to increments of ME, particularly beyond twice maintenance, has been recognized (Blaxter \& Boyne, 1978; Agricultural Research Council, 1980). Cammell et al. (1986) used an exponential model, based on the Mitscherlich equation, to resolve responses $\left(k_{f}\right)$ to increments in MEI above 1.65 M and to extrapolate between derived $E_{m}$ and measured FHP. Implicit in such a model was the assumption that there was no pronounced sigmoidicity below maintenance.

The results from the present study demonstrate linearity of response between fasting metabolism (where $\mathrm{MEI}=0$ and $\mathrm{RE}=0-\mathrm{FHP}$ ) and $1.25 \mathrm{M}$. Curvilinearity in the relationship was introduced when UE losses were included with FHP, but linearity was restored when FE was partitioned as negative MEI. The partitioning of such energy losses during fasting metabolism may be a matter of semantics but, nevertheless, was of importance in the present study in that the slope of the linear response agreed with measured $k_{m}$ only when appropriate account was made of these values. However, from the evidence presented it would appear that the definition of response relationships obtained in the present study at between $0.25 \mathrm{M}$ and $1.25 \mathrm{M}$ was not significantly improved by the measurement of fasting metabolism, thus questioning further the relevance of measurements from fasting animals as an adjunct to the interpretation of production responses by animals fed well in excess of their nutritional maintenance requirements.

It was noted that, despite the high proportion of variance accounted for by the relationships described in equations 6-13 for the treatment levels used in the present study, the derived $E_{m}$ values for both groups 1 and 2 were significantly lower $(P<0.05)$ than either observed maintenance energy requirement or maintenance corrected to the convention described by Van Es (1972) and the Agricultural Research Council (1980). These findings support previous observations where cattle have been shown to adapt their maintenance requirements over long periods of time when maintained at constant LW (Foot \& Tulloh, 1977; Ledger \& Sayers, 1977). Such divergence by the predictive relationships would indicate that either true zero energy balance had not been established at day 56, due to an inadequate length of time to stabilize metabolism (Turner \& Taylor, 1983), or that during the prolonged period of $84 \mathrm{~d}$ of restricted feeding that physiological and metabolic 'conditioning' had occurred which did not extrapolate to biologically comparable values for measured $E_{m}$ in young animals which were initially primed for growth. This observation lends further credence to the concept that values for maintenance derived from physiologically-dormant animals are of limited relevance to actively-growing and fattening livestock. 
The mechanisms consequent on the levels of nutrition required to sustain a highly productive ruminant have been subject to much attention; the views of Brody (1945), Kromann (1973), Graham (1982), Baldwin \& Bywater (1984) and Webster (1988) represent some of the perceptions of the difficulties associated with the prediction of levels of production per unit food consumed whilst using a benchmark of nutritional requirement for maintenance. The interaction of variables such as environmental conditions, plane of nutrition, level of production, synthesis of fat and/or protein, physiological status and metabolic activity of major organs and tissues including both functional and storage organs and tissues have a potential impact on the accuracy of prediction of $E_{m}$ and, thus, RE.

In the present study it could be postulated that the difference in predicted $E_{m}$ between groups 1 and 2 and the observed values could be attributed to changes in physiological and metabolic variables which were acquired over a long period of reduced nutrition. Whilst the approach adopted in the present study to the definition of $E_{m}$ may follow accepted historical methodology, the results support the philosophy that FHP, $k_{m}$ and $E_{m}$ (measured or derived) are systematically acquired observations whose value depends on the protocol adopted for their measurement (Webster, 1978).

Currently about $40 \%$ of ME supplied to ruminants is consumed by a process from which there are no tangible returns, this alone should be sufficient to focus attention on the quantification and revision of the term $E_{m}$ in such a way as to reflect the physiological status and metabolic requirement of productive ruminants maintained in variety of environmental conditions.

The authors would like to thank Mr M. C. Spooner, Mr P. R. Cornell, Mr A. R. Austin, Mr K. V. Skelton, Mr R. J. Barnes, Mr R. B. Marshall and Dr J. C. Alliston.

This work formed part of a commission from the Ministry of Agriculture, Fisheries and Food.

\section{REFERENCES}

Agricultural Research Council (1980). The Nutrient Requirements of Farm Livestock. no. 2. Ruminants. Farnham Royal: Commonwealth Agricultural Bureaux.

Armstrong, D. G. \& Blaxter, K. L. (1984). Maintenance requirement; implications for its use in feed evaluation systems. In Herbivore Nutrition in the Subtropics and Tropics. [F. M. H. Gilchrist and R. I. Mackie, editors]. Craighall, S.A.: The Science Press.

Baldwin, R. L. \& Bywater, A. C. (1984). Nutritional energetics of animais. Annual Review of Nutrition 4, $101-114$. Blaxter, K. L. (1962). The Energy Metabolism of Ruminants, London: Hutchinson.

Blaxter, K. L. (1972). Festskrift til Professor K. Brierem, pp. 19-36. Oslo: Mariendals Boktrykkeri.

Blaxter, K. L. \& Boyne, A. W. (1970). In Energy Metabolism of Farm Animals, European Association for Animal Production no. 13, pp. 9-13 [A. Schurch and C. Wenk, editors]. Vitznau, Switzerland: Juris Verlag.

Blaxter, K. L. \& Boyne, A. W. (1978). The estimation of the nutritive value of feeds as energy sources for ruminants and the derivation of feeding systems. Journal of Agricultural Science, Cambridge 90, 47-68.

Blaxter, K. L. \& Graham, N. McC. (1955). Plane of nutrition and starch equivalents. Journal of Agricultural Science, Cambridge 46, 292-306.

Blaxter, K. L. \& Wainman, F. W. (1961). The utilization of food by sheep and cattle. Journal of Agricultural Science, Cambridge 57, 419-425.

Blaxter, K. L. \& Wainman, F. W. (1966). The fasting metabolism of cattle. British Journal of Nutrition 20 , 103-111.

Brody, S. (1945). Bioenergetics and Growth. New York: Reinhold Publishing.

Brouwer, E. (1965). Report of the sub-committee on constants and factors. In Energy Metabolism, European Association for Animal Production Publication no. 11, pp. 441-443 [K. L. Blaxter, editor]. London: Academic Press.

Cammell, S. B. (1977). Equipment and techniques used for research into the intake and digestion of forages by sheep and cattle. Technical Report no. 24, Hurley: Grassland Research Institute.

Cammell, S. B., Beever, D. E., Skelton, K. V. \& Spooner, M. C. (1981). The construction of open-circuit calorimeters for measuring gaseous exchange and heat production in sheep and young cattle. Laboratory Practice 30, 115-119.

Cammell, S. B., Thomson, D. J., Beever, D. E., Haines, M. J., Dhanoa, M. S. \& Spooner, M. C. (1986). The 
efficiency of energy utilization in growing cattle consuming fresh perennial ryegrass (Lolium perenne cv. Melle) or white clover (Trifolium repens cv. Blanca). British Journal of Nutrition 55, 669-680.

Foot, J. Z. \& Tulloh, N. M. (1977). Effects of two paths of liveweight change on the efficiency of feed use and on body composition of Angus steers. Journal of Agricultural Science, Cambridge 88, 135-142.

France, J., Dhanoa, M. S., Cammell, S. B., Gill, M., Beever, D. E. \& Thornley, J. H. M. (1989). On the use of response functions in energy balance analysis. Journal of Theoretical Biology 140, 83-99.

Graham, N. McC. (1982). Energy feeding standards: A methodological problem. In Energy Metabolism of Farm Animals, European Association for Animal Production no. 29, pp. 108-111 [A. Ekern and F. Sundstøl, editors]. Norway: Agricultural University.

Kromann, R. P. (1973). Evaluation of net energy systems. Journal of Animal Science 37, 200-212.

Ledger, H. P. \& Sayers, A. R. (1977). The utilization of dietary energy by steers during periods of restricted food intake and subsequent realimentation. I. The effect of time on maintenance requirements of steers held at constant live weights. Journal of Agricultural Science, Cambridge 88, 11-16.

Taylor, St C. S. \& Young, G. B. (1967). Variation in growth and efficiency in twin cattle on constant feeding levels. Animal Production 9, 295-311.

Taylor, St C. S. \& Young, G. B. (1968). Equilibrium weight in relation to food intake and genotype in twin cattle. Animal Production 10, 393-412.

Terry, R. A., Osbourn, D. F., Cammell, S. B. \& Fenlon, J. S. (1974). In vitro digestibility and estimation of energy in herbage. In Proceedings of the 5th General Meeting of the European Grasstand Federation, Uppsala 1973, Vaxtodling 28, 19-25.

Turner, H. G. \& Taylor, St C. S. (1983). Dynamic factors in models of energy utilisation with particular reference to maintenance requirement of cattle. World Review of Nutrition and Dietetics 42, 135-190.

Van Es, A. J. H. (1961). Verslagen van Landbouwkundige Onderzockingen 67, 5.

Van Es, A. J. H. (1972). In Handbuch der Tierernährung, Vol. 2, p. 1. (W. Lenkeit, K. Briet and E. Crasemann, editors) Berlin: Paul Parey.

Vermorel, M., Bouvier, J. C. \& Geay, Y. (1980). Energy utilization by growing calves: effects of age, milk intake and feeding level. In Energy Metabolism of Farm Animals, European Association for Animal Production no. 26 , pp. 49-53 [L. E. Mount, editor]. London: Butterworths.

Webster, A. J. F. (1978). Prediction of the energy requirements for growth in beef cattle. World Review of Nutrition and Dietetics 30, 189-226.

Webster, A. J.F. (1988). Comparative aspects of the energy exchange. In Comparative Nutrition, pp. 37-54 [K. L. Blaxter and I. MacDonald, editors]. London: John Libbey.

Webster, A. J. F., Smith, J. S. \& Mollison, G. S. (1982). In Energy Metabolism of Farm Animals, European Association for Animal Production no. 29, pp. 84-87 [A. Ekern and F. Sundstøl, editors]. Norway: Agricultural University.

Williams, E. J. (1959). Regression Analysis, pp. 96. London: Chapman and Hall. 